\title{
USING INTEGRATED ASSESSMENT TO MEASURE STUDENTS' ANALYTICAL THINKING AND SCIENCE PROCESS SKILLS
}

\author{
Irwanto $^{1}$, Eli Rohaeti ${ }^{2}$ \\ ${ }^{1}$ Doctoral Program in Educational Sciences, Yogyakarta State University \\ ${ }^{2}$ Chemistry Education Lecturer, Graduate School of Yogyakarta State University \\ Yogyakarta, Indonesia \\ ${ }^{1}$ E-mail : Irwanto.2016@student.uny.ac.id
}

\begin{abstract}
Science process skills (SPS) are the tools that are needed in chemistry learning in $21^{\text {st }}$ century. SPS are thinking skills that used to build knowledge in problems solving. SPS aim to measure thinking skills and create active learning. SPS based learning can also enhance the knowledge of students towards science. In the other words, SPS have positive relationship with the cognitive domain, including the analytical thinking skills. Analytical thinking is one of a high order thinking skills that are used to elaborate, attribute, and analyze information to understand the knowledge using logical thinking. Analytical thinking is the thinking that is based on facts which will help in solving the problems and finding the solutions that supports critical and creative thinking. To measure both the competencies needed an integrated assessment instrument which able to measure the students' achievement effectively and efficiently. Integrated assessment is an interdisciplinary process in combining, interpreting, communicating knowledge and abilities of students from a variety of sources. In summary, if the integrated assessment is done effectively by utilizing the data collection, analysis, and management of the various actions that are integrated into the teaching process, it will improve the students' analytical thinking and science process skills.
\end{abstract}

Keywords: Analytical Thinking, Integrated Assessment, Science Process Skills

\section{INTRODUCTION}

Chemistry is the science acquired and developed based on the results of research to find answers to questions of what, why, and how these natural phenomena occured and interconnected. Theoretically, learning about the chemical composition, formation, structure, properties, material changes, and energy that accompany these changes [1], involving a variety of skills and high-level reasoning. Therefore, the learning of chemistry must consider the characteristics of chemistry as process and product.

Characteristics of process chemistry as related to the skills and attitudes required students to acquire, develop knowledge, and face problems through scientific activities. The activity aims to enhance the knowledge and discovering new knowledge. While the characteristics of chemistry as related to the knowledge of chemical products in the form of facts, concepts, principles, laws, and theories is born of scientific thought processes [2].

In essence, the learning process chemistry emphasizes on direct experience of students to develop competencies through practical activities. It's main activity requires specific skills that can support problem solving. One of the skills needed in chemistry learning in the $21^{\text {st }}$ century is the science process skills [3].

During this time, students are many who think that the concept of chemistry in general abstract [4]. The concept includes the ability to represent and interpret the problem macroscopic, microscopic, and symbolic [5]. Thus, these difficulties need to look for solutions in order to improve motivation and learning outcomes of students. One way that can be used by teachers to improve students understanding of the chemistry is the use of inquiry-based learning in the laboratory.

Inquiry-based learning is a concept of learning that encourages teachers to connect students with authentic situations, explore, and solve problems in real life [6]. Through the activities of exploration, 


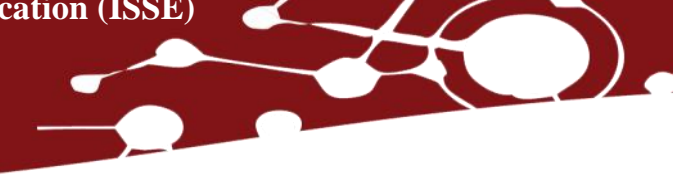

investigation and observation, students will engage in social interaction as well as the use of high-level thinking to broaden and deepen the knowledge [7-8]. High-level thinking includes therein is the analytical thinking ability. Thus, analytical thinking can be used as a basis for understanding the facts, concepts, principles, laws, and theoretical chemistry who require high abstraction. Furthermore, the result of conceptual understanding is used to determine the procedural framework and strengthens the argument lab results.

Analytical thinking is one of cognitive domain needed in the experiment. Event experiments can involve all or a combination of science process skills. In the other words, SPS have positive relationship with the cognitive domain [9-10], including the analytical thinking. To measure both the competencies needed an integrated assessment instrument which able to measure the students' achievement effectively and efficiently.

\section{LITERATURE REVIEWS AND DISCUSSIONS}

\section{A. Analytical Thinking Abilities (ATA)}

The course emphasizes the basic concepts of analytical thinking including the decomposition of complex problems, the logic of drastic simplification, the dynamics of first-cut and successive-cut analyses, the importance of being specific, the rationale for working with numbers, and the analytics of guesstimation [11]. Analytical thinking abilities influenced by the ability of students in applying, rearranging, and adding to the knowledge of the situation or environment in which the individual is located [12].

Analytical thinking abilities have some indicators can be developed through problem-based learning activities. In general, the analytical thinking classified into three types [13]:

a. Differentiating; the ability to isolate, sort, select, and focused;

b. Organizing; the ability to find, coherence, integrate, describe the role and structure;

c. Attributing; the ability to determine the angle of view or the underlying value of the material presented.

Based on various opinions, it can be concluded that analytical thinking is one of a high order thinking skills that are used to elaborate, attribute, and analyze information to understand the knowledge using logical thinking. Furthermore, analytical thinking is the thinking that is based on facts which will help in solving the problems and finding the solutions that supports critical and creative thinking..

B. Science Process Skills (SPS)

Science process skills are skills needed by students to solve problems in scientific activities in an authentic way [14]. The opinion was reinforced by Ajoke and Joe [15] which states that the science process skills are skills required by each individual in daily life to improve the quality and standard of living.

Tek and Ruthven [16] classifies 11 types of capabilities that can be developed through learning activities based approach science process skills:

a. Observing; the process of gathering information about the object or phenomenon using all or part of the sensory organs;

b. Classifying; observe and identify the similarities and differences between objects or phenomena, and categorize them in terms of similar characteristics;

c. Measuring; observing quantitatively using standardized instruments;

d. Concluding; provide an explanation for the observation or object;

e. predicting; the process of predicting what might happen based on observation and previous experience as well as the relevant data;

f. Communicating; presenting ideas or information in various forms such as oral, written, using charts, diagrams, models, tables, and symbols;

g. Interpreting data; process give a rational explanation of the object, event or pattern of some data collection;

h. Operational definition; making the definition of each variable in accordance with the functions and how to conduct and measure it;

i. Controlling the variables; identify, manipulate, and responding variable in an investigation; 
j. Formulating hypotheses; the ability to draw up a statement explaining the circumstances and examine the statement to prove its validity;

k. Conducting experiments; conduct an investigation to test the hypothesis. Experimental activities involving all or a combination of other process skills.

Harlen [17] describes five aspects to be considered by teachers in developing science process skills:

a. Providing the opportunity to use the skills in the process of exploration of matter and phenomena;

b. Giving the opportunity to work in small groups and class discussions;

c. Listening to students and learn about their products to find the necessary process in forming new ideas;

d. Encouraging students to review critically about how the activities they have done;

e. Providing techniques or strategies to improve their skills, particularly in observation and measurement accuracy, or techniques that need to be developed in communication.

Based on various opinions, it can be concluded that the science process skills are skills needed by students to solve problems in the exploration of matter and phenomena in real life.

\section{The Relationship between ATA and SPS}

Science process skills linked to cognitive domains students, including the analytical thinking abilities [18]. In general, the relationship between the conceptual frame-work of cognitive dimension with science process skills is presented in Figure 1.

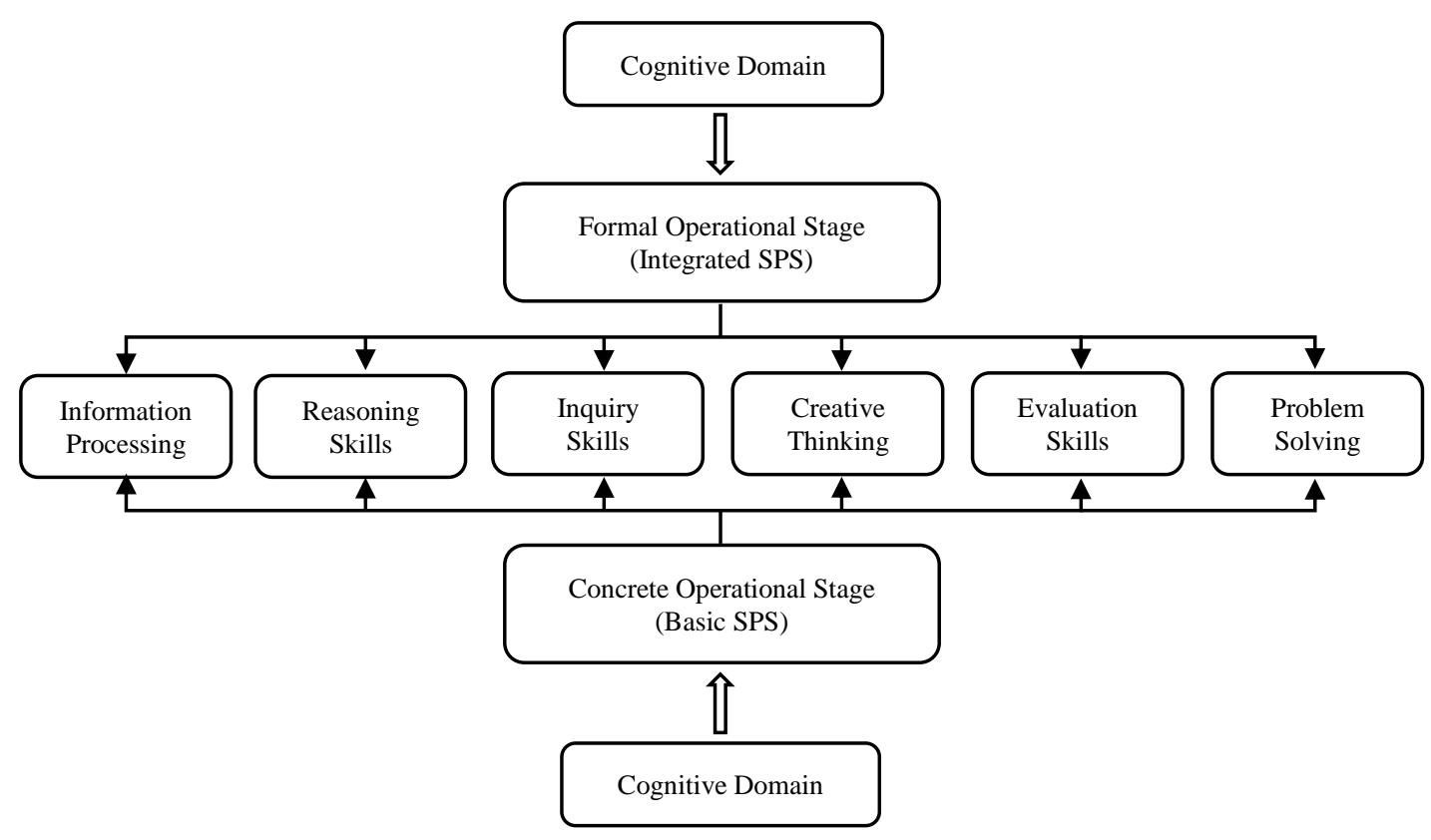

FIGURE 1. THE RELATIONSHIP BETWEEN ATA AND SPS [18]

Results were confirmed by Oloyede [19] indicate that there is a positive relationship between science process skills in reasoning abilities and achievements of chemistry. Students are equipped with science process skills tend to be more successful and analytical thinking in solving new problems than those who are not equipped with science process skills. Thus, the use of science process skills in the learning process is the basis for the development of students' knowledge further. Additionally, another benefit of the development of science process skills which frees students from the anxiety can hamper the achievement of the results of cognitive and affective [20].

\section{Integrated Assessment}

Integrated assessment is an assessment focused on the ability of students to solve complex and unstructured [21]. In general, an integrated assessment model combines sub-models of various disciplines 
into a single framework and then analyzes the interactions that occur between different systems [22]. Increasing the relevance and validity of the results of students using integrated assessment approach has a better quality than using single vote [23].

In practice, the integrated assessment requires a rubric scoring guidelines in order to avoid subjectivity in assessing teachers. Scoring form of partial credit the integrated assessment model that requires several steps to resolve. The assessment is done by giving a score to each step that has been done correctly students. Examples of the preparation of guidelines for the integrated assessment scoring partially presented in Table 1.

TABLE 1. SCORING GUIDELINES

\begin{tabular}{clc}
\hline No. & \multicolumn{1}{c}{ Scoring Steps } & Score \\
1. & Writing out the work steps & 1 \\
2. & Writing out the formula of mole (n) & 1 \\
3. & Calculating the number of moles & 1 \\
4. & Writing out the formula of concentration $(\mathrm{M})$ & 1 \\
5. & Calculating the concentration of the solution & 1 \\
6. & Writing out the formula of dilution & 1 \\
7. & Calculating the concentration after dilution & 1 \\
\hline
\end{tabular}

In connection with the evaluation process, Birenbaum et al. [24] suggested some key principles that need to be considered in assessing an integrated:

a. Students participate in the evaluation process;

b. Ratings contextual teaching that has been done;

c. Material valuation is adjusted with the knowledge and ability of students;

d. Evaluate the learning process and learning products;

e. Presenting the evaluation criteria transparent for students and teachers;

f. Students and teachers to get feedback about the results of the assessment;

g. Inform students and teachers about their progress in learning.

Based on that opinion, it can be concluded that the integrated assessment is an assessment of learning outcomes of students who combine domain knowledge and skills. Integrated assessment aims to assess the science process skills and analytical thinking skills of students in solving complex problems through scientific learning.

\section{Conclusions And Suggestions}

SPS have positive relationship with the cognitive domain, including the analytical thinking abilities. To measure both the competencies needed an integrated assessment instrument which able to measure the students' achievement effectively and efficiently. In summary, if the integrated assessment is done effectively by utilizing the data collection, analysis, and management of the various actions that are integrated into the teaching process, it will improve the students' analytical thinking and science process skills that are needed in chemistry learning in $21^{\text {st }}$ century.

\section{REFERENCES}

[1] O.A. Adepoju, "Mnemonic as an innovative approach to creative teaching of secondary school chemistry", African Journal of Chemical Education, 4(2), pp.122-138, 2014.

[2] D. Cheung, "Analyzing the Hong Kong Junior Secondary Science Syllabus Using the Concept of Curriculum Orientations", Educational Research Journal, 15(1), pp.69-94, 2000.

[3] L. Monhardt, and R. Monhardt, "Creating a context for the learning of science process skills through picture books", Early Childhood Education Journal, 34(1), pp.67-71, 2006.

[4] T.L. Nahum, A. Hofstein, R. Mamlok-Naaman, and Z. Bar-Dov, “An final examinations amplify students' misconceptions in chemistry?”, Chemistry Education: Research And Practice, 5(3), pp.301-325, 2004.

[5] M. Tuysuz, B. Ekiz, O. Bektas, E. Uzuntiryaki, A. Tarkin, and E.S. Kutucu, "Pre-service chemistry teachers' understanding of phase changes and dissolution at macroscopic, symbolic, and microscopic levels", Procedia Social and Behavioral Sciences, 15, pp.452-455, 2011.

[6] D.D. Li, and C.P. Lim, "Scaffolding online historical inquiry tasks: a case study of two secondary school classrooms". Computers \& Education, 50(4), pp.1394-1410, 2008.

[7] J.-L. Shih, C.-W. Chuang, and G.-J. Hwang, "An inquiry-based mobile learning approach to enhancing social science learning effectiveness". Educational Technology \& Society, 13(4), pp.50-62, 2010. 
[8] C. Rooney, "How am I using inquiry-based learning to improve my practice and to encourage higher order thinking among my students of mathematics?", Educational Journal of Living Theories 5(2), pp.99-127, 2012.

[9] M.N. Sheeba, "An anatomy of science process skills in the light of the challenges to realize science instruction leading to global excellence in education". Educationia Confab, 2(4), pp.108-123, 2013.

[10] A.F. Zeidan, and M.R. Jayosi, "Science process skills and attitudes toward science among palestinian secondary school students". World Journal of Education, 5(1), pp.13-24, 2015.

[11] R.D. Behn, and J.W. Vaupel, "teaching analytical thinking”. Policy Analysis, 2(4), pp.663-692, 1976.

[12] F.J. King, L. Goodson, and F. Rohani, Higher Order Thinking Skills. Tallahassee, Florida: CALA, 1997.

[13] R.E. Mayer, "Rote versus meaningful learning”. Theory Into Practice, 41(4), pp.226-232, 2002.

[14] M.V. Lanka, "A framework for identifying performance indicators of effective science process skills teaching in botswana senior secondary physics". World Transactions on Engineering and Technology Education, 6(1), pp.63-66, 2007.

[15] A.A. Ajoke, and N.P. Joe, "Creativity and process skills for self- reliance using demonstration approach of teaching chemistry. ARPN Journal of Science and Technology, 2(11), pp.1029-1033, 2012.

[16] O.E. Tek, and K. Ruthven, "Acquisition of science process skills amongst form 3 students in malaysian smart and mainstream schools". Journal of Science and Mathematics Education in S.E. Asia, 28(1), pp.103-124, 2005.

[17] W. Harlen, The Teaching of Science: Studies in Primary Education. London: David Fulthon Publishing Company, 1992.

[18] S. Özgelen, "Students' science process skills within a cognitive domain framework". Eurasia Journal of Mathematics, Science \& Technology Education, 8(4), pp.283-292, 2012.

[19] O.I. Oloyede, "The relationship between acquisition of science process skills, formal reasoning ability and chemistry achievement". International Journal of African and African American Studies, 8(1), pp.1-4, 2012.

[20] A.A. Aderogba, and O.S. Oyelekan, "Enhancing transformative science education in nigeria through the use of science process skills". International Journal of Contemporary issues in Education, 2, pp.206-212, 2010.

[21] B.A. van Asselt Marjolein, and N. Rijkens-Klomp, "A look in the mirror: reflection on participation in integrated assessment from a methodological perspective". Global Environmental Change, 12, pp.167-184, 2002.

[22] E.G.R. Davies, P. Kyle, and J.A. Edmonds, "An integrated assessment of global and regional water demands for electricity generation to 2095". Advances in Water Resources, 52, pp.296-313, 2013.

[23] L. Acosta-Michlik, W. Lucht, A. Bondeaum, and T. Beringer, "Integrated assessment of sustainability trade-offs and pathways for global bioenergy production: framing a novel hybrid approach". Renewable and Sustainable Energy Reviews, 15, pp.2791$2809,2011$.

[24] M. Birenbaum, K. Breuer, E. Cascallar, F. Dochy, Y. Dori, J. Ridgway, R. Wiesemes, and G. Nickmans, "a learning integrated assessment system". Educational Research Review, 1, pp.61-67, 2006. 